\title{
COMPARATIVE HISTOLOGY OF CONODONTS AND EARLY VERTEBRATES
}

\author{
A. V. Zhuravlev \\ Institute of Geology Komi SC UrB RAS, Syktyvkar \\ micropalaeontology@gmail.com
}

The study of the histology of the Late Devonian and Early Carboniferous conodont elements allows characterizing the main types of hard tissues, composing a conodont element crown: lamellar, paralamellar, interlamellar, and albid. Significant differences between texture and composition of the conodont hard tissues and those of Vertebrata are detected. Some similarities observed in the structures of the conodont and vertebrate mineralized tissues may be caused by similar process of biomineralization, not by synplesiomorphy.

Keywords: Conodonta, histology, hard tissues, Late Devonian, Early Carboniferous, Vertebrata.

\section{СРАВНИТЕЛЬНАЯ ГИСТОЛОГИЯ КОНОДОНТОВ И РАННИХ ПОЗВОНОЧНЫХ}

\author{
А. В. Журавлев \\ Институт геологии Коми НЦ УрО РАН, Сыктывкар \\ micropalaeontology@gmail.com
}

\begin{abstract}
Изучение гистологии позднедевонских и раннекаменноугольных конодонтовых элементов позволило охарактеризовать основные типы тканей, формирующих крону конодонтовых элементов: ламеллярную, параламеллярную, интерламеллярную и альбидную. Отмечены существенные различия в текстуре и составе твердых тканей конодонтов и позвоночных. Наблюдаемое некоторое сходство в текстуре минерализованных тканей конодонтов и позвоночных может быть обусловлено сходными процессами биоминерализации, а не синплезиоморфией.
\end{abstract}

Ключевые слова: конодонты, гистология, твердые ткани, поздний девон, ранний карбон, позвоночные.

\section{Introduction}

Conodonts are extinct group of marine animals, which was considered as a specific group of Vertebrata (Purnell et al., 1995; Donoghue et al. 2000) or Chaethognatha (Kasatkina, Buryi, 1999; Murdock et al., 2013). The only mineralized part of the animals is a feeding apparatus composed of fifteen (up to nineteen in some prioniodinids) tooth-like conodont elements. There are four groups of elements distinguished by position in the apparatus (Fig. 1). Anteriormost element pair, named $\mathrm{M}$ elements, and nine anterior elements ( $\mathrm{S}$ elements) demonstrate coniform or ramiform morphology. Posterior elements pairs $(\mathrm{Pb}$ and $\mathrm{Pa}$ elements) vary greatly in morphology, and can be coniform, ramiform, bladeform, or platform. All the conodont elements consist of two parts - crown and basal filling. The crowns are more resistant in the fossilization processes, and are better preserved. Four types of hard tissue, namely lamellar, paralamellar, interlamellar, and albid (or "white matter") tissues compose conodont element
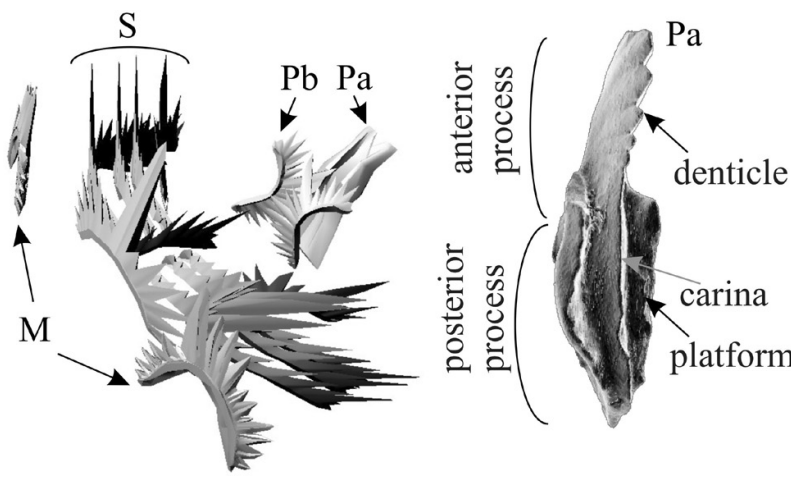

Fig. 1. Schematic drawing of the ozarkodinid conodont apparatuses and notations of conodont elementtypes

Рис. 1. Схематическое изображение озаркодинидного конодонтового аппарата и типы конодонтовых элементов crown (Zhuravlev, 2002). All the tissues are composed of the organic matter and crystallites of calcium phosphate (F-apatite) (Wright, 1990; Rosseeva et al., 2011; FrankKamenetskaya et al., 2014).

Histological terminology related to conodont elements was developed since classic work of $\mathrm{H}$. Pander (1856). Two main stages of conodont histology study can be recognised. The first one comprises histological investigations done with the optic techniques. The major results of this stage were considered by K. Mbller and Y. Nogami (1971, 1972), M. Lindstrom and W. Ziegler (1971). The principal types of hard tissue (lamellar or hyaline, "white matter" or albid, and interlamellar tissues) and their characteristics were recognized. Introduction of scanning electron microscope into histological investigations begun by R. Pierce and R. Langenheim (1969) allowed improving and broadening our knowledge about the crystalline composition and characteristic features of the hard tissue types. For example, heterogeneity of the albid tissue was discovered. Detailed study showed that this tissue type was represented by at least two different subtypes. These subtypes differed one from another by different crystalline arrangement and microstructure (e. g. Barnes et al. 1973, 1975). Comprehensive review of the recent state of the art in conodont hard tissue histology was done by Ph. Donoghue (1998). Subsequent works permitted to elaboratea classification of conodont hard tissues (Zhuravlev, 2002).

Histological features of the conodont elements were considered as an evidence of conodont-vertebrates relations (Sansom et al., 1992; Briggs, 1992; Janvier, 1995; Donoghue, 1998). However, the homology or analogy between the conodont hard tissues and that of true vertebrates remains an open question (Turner et al., 2010; Blieck et al., 2010; Murdock et al., 2013). A comparative study of the histology of conodont elements and vertebrate hard tissues promises deciphering of the affinities of these groups. 
The following homologies had been supposed: lamellar tissue - enamel or enameloid (Sansom et al., 1992; Briggs, 1992); lamellar tissue - lamellar dermal bone (Sansomet al., 1992); albid tissue - dentine (Sansom et al., 1994); albid tissue - cellular bone (Sansom et al., 1992; Briggs, 1992); albid tissue - mesodentine (Janvier, 1995).

This work is aimed to:

- characterize the main features of conodont element tissues.

- compare these features with main characteristics of the vertebrate tissues, which was been considered as homologous to the conodont tissues.

\section{Material and methods}

The collection of the Late Devonian (the Middle Frasnian, punctata conodont Zone) conodont elements was used for multidisciplinary study of the hard tissues. The conodont elements were collected from the bioclastic limestones of the Il'men and Buregi formations of the Il'men Lake district, NW of the East European Platform (Zhuravlev et al., 2006). Good preservation, weak thermal alteration of the conodont elements (Conodont Alteration Index (CAI) is 1), and assumed high rate of lithification of the carbonate host rocks promised a conservation of the primary composition and structure, including organic matter. Additional material from the deep-water Early Carboniferous (the Late Tournaisian, quadruplicata conodont Zone)calciturbidites of the Subpolar Urals (Kozhym River sections; CAI $=5$ ) and the Late Visean of the East European Platform (Moscow Syneclise, KalinovskieVyselki section, material provided by Dr. A.O. Ivanov; CAI = 1) was used as well. The studied conodont elements demonstrate all the known types of tissues, namely lamellar, interlamellar, paralamellar, and albid tissues.

Collected samples were processed with conventional buffered acetic acid technique. Pollutant organic matter was removed with $95 \%$ ethanol. The following methods were used for the tissues study: optic microscopy of the thin and polished sections, SEM, microprobe, XRD, and X-Ray microtomography (see also Zhuravlev, Sapega, 2007; Rosseeva et al., 2011; Zhuravlev, Gerasimova, 2015). Additionally the demineralized tissues of the Late Devonian Youngquistognathus were studied with VanGieson trichrome staining and XRD (Zhuravlev, Sapega, 2007; Zhuravlev, Gerasimova, 2015).

\section{Results and discussion}

The study of conodont elements by a number of methods allows to characterize all the tissue types and to compare the parameters of the tissues with those of vertebrates.

\section{Lamellar tissue}

This tissue type is most common in the conodont elements. The tissue is composed of crystallites of calcium phosphate (F-apatite) aligned on prismatic and pinacoidal crystal faces (Lindstrum\& Ziegler, 1971; Wright 1990). Lamellar tissue demonstrates clear lamellar structure, each of the lamellae is $0.6-4 \mu \mathrm{m}$ thick and comprises a set of slightly disordered crystallites $(0.2-0.6 \mu \mathrm{m}$ thick and $0.6-$ $4 \mu \mathrm{m}$ long), with c-axis oriented subparallel or oblique to the surface of lamella in the denticles, and subperpendicu-

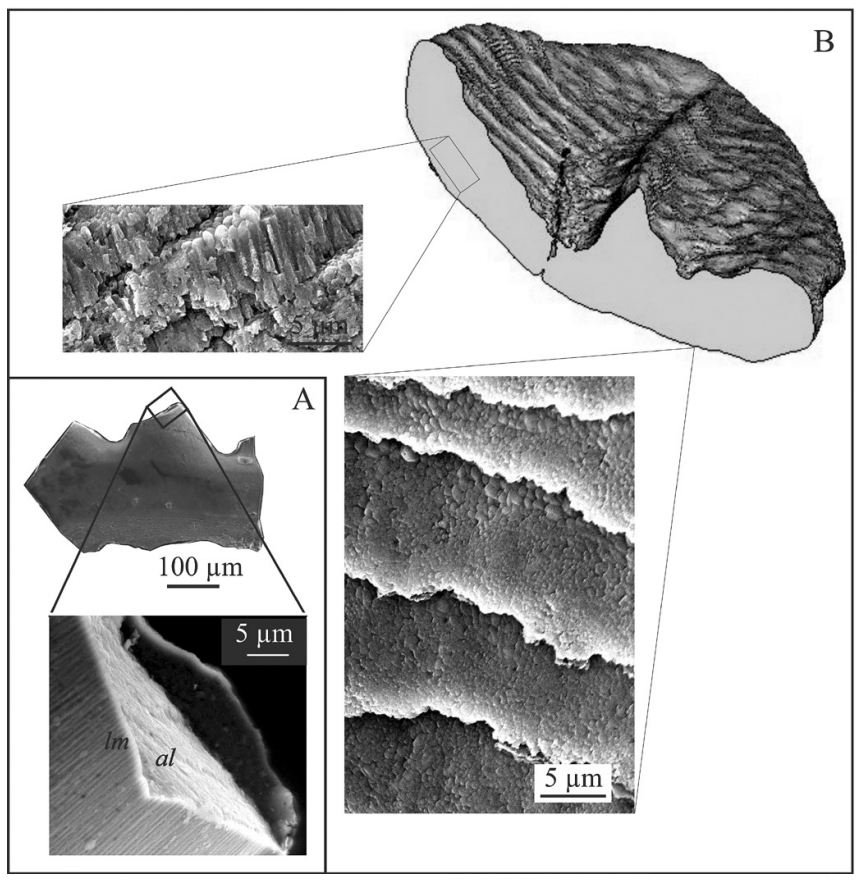

Fig. 2. Lamellar tissue structure. A - Lamellar and albid tissues junction in the denticle of the S element of the Middle Frasnian Polygnathida. B - SEM images of the crystallites of the lamellar tissue in the platform of Pa element of the Late Tournaisian Siphonodella quadruplicate (Branson et Mehl)

Рис. 2. Текстура ламеллярной ткани: А - сочленение ламеллярной и альбидной тканей в зубце $\mathrm{S}$-элемента среднефранской полигнатиды; В - СЭМ-изображения кристаллитов ламеллярной ткани в платформе Ра-элемента позднетурнейского вида Siphonodella quadruplicata (Branson et Mehl)

lar to the surface of lamella in the platforms (Fig. 2) (see also Lindstrцm\& Ziegler, 1971; Wright 1990). It is supposed that the crystallite orientation depends on the superposition of conodont element surface and secretory epithelium cells (Zhuravlev, 2002). The lattice parameters of lamellar tissue apatite $(\mathrm{a}=9.365, \mathrm{c}=6.880 \AA)$ are far from those of stoichiometric F-apatite (Zhuravlev, Sapega, 2007). The $\mathrm{Ca} / \mathrm{P}$ ratio (wt. \%) in the lamellar tissue of the unaltered conodont elements $(\mathrm{CAI}=1)$ is about 2.12 according to the microprobe data.

Organic matter composed of collagen (SDS Page electrophoresis data, see Rosseeva et al., 2011), forms thin films on the boundaries of crystallites and probably fills the nanopores. Total content of organic matter is about $3 \mathrm{vol} . \%$ (Zhuravlev, Gerasimova, 2015). Presence of the collagen in this tissue type was supported by histochemical (Kemp, 2002; Gerasimova et al., 2015; Zhuravlev, Gerasimova, 2015) and XRD data (Zhuravlev, Sapega, 2007) as well. The collagen preservation over hundreds of millions years can be explained by a high degree of isolation of the organic matter in the conodont elements from the environmental changes due to close incorporation of the collagen fibrils into the mineralized matrix. This incorporation prevents decaying of the organic matter.

The lamellae composed of lamellar tissue cover the whole oral surface of the conodont element crown, overlaying the structures composed of other tissue types (Fig. 2).

The regeneration traces are common in the lamellar tissue. This tissue type is regenerated by the same tissue only (Zhuravlev, 2004). 


\section{Interlamellar tissue}

The interlamellar tissue is similar to lamellar one in texture and structure, but differs in organic matter content (more than 4 vol.\%) and low crystallity. Hardly ordered small crystal units (about $0.4-0.6 \mu \mathrm{m}$ ) are covered by organic matter, so the interlamellar tissue demonstrates bubble-like structure. In some cases the elongated crystallites are oriented obliquely to the lamellae surface (Fig. 3). Regeneration is not common for this tissue type.

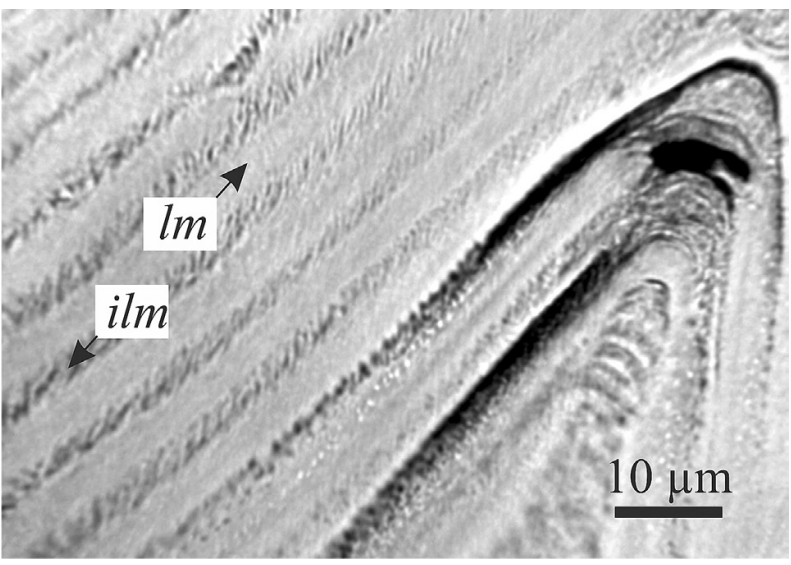

Fig. 3. Lamellar and interlamellar tissues in the denticle of the $\mathrm{S}$ element of the Late Visean Idioprioniodus claviger (Roundy). Legend: $l m-$ lamellar tissue, ilm - interlamellar tissue. Optic microscopy in immersion

Рис. 3. Ламеллярная и интерламеллярная ткани в зубце $\mathrm{S}$-элемента поздневизейского Idioprioniodus claviger (Roundy). Условные обозначения: $\mathrm{lm}$ - ламеллярная ткань, $\mathrm{ilm}$ - интерламеллярная ткань. Оптическая микроскопия в иммерсии

\section{Albid tissue}

The albid tissue is a specific tissue type composing the cores of denticles of the main processes of a conodont element, and is always covered with a layer of the lamellar tissue (Fig. 2). This tissue type is never observed in other parts of conodont elements. It is considered as a conodont subclade autapomorphy (Donoghue, Chauffe, 1998).

Albid tissue is composed of micrometer-sized crystallite subunits with preferable crystallographic orientation run parallel to the long axis of the denticle (Wright 1990; Rosseeva et al., 2011). The units compose porous mesocrystal, looking like a monocrystal in electron diffraction and cross-polarized light (Rosseeva et al., 2011; Frank-Kamenetskaya et al., 2014). The lattice parameter of albid tissue apatite $(\mathrm{a}=9.374-9.376, \mathrm{c}=6.882-$ $6.892 \AA$ ) is very close to that of stoichiometric synthetic F-apatite (Zhuravlev, Sapega, 2007; Frank-Kamenetskaya et al., 2014). The $\mathrm{Ca} / \mathrm{P}$ ratio (wt. \%) in the albid tissue of the unaltered conodont elements $(\mathrm{CAI}=1)$ is $2.09 \mathrm{ac}-$ cording to the microprobe data. In spite of high crystallinity, albid tissue demonstrates lamellar structure, comparable with the structure of lamellar and paralamellar tissues (Trotter et al., 2007; Gerasimova et al., 2015; Zhuravlev, Gerasimova, 2015). The mesocrystal texture is a unique feature of the albid tissue, which is never observed in any Vertebrata hard tissues.

The low content of the organic matter (less than 1 vol. \%) and high mineralization are characteristic of the albid tissue (Zhuravlev, Gerasimova, 2015). The organ- ic matrix is the same as in other tissues, and is composed of collagen-like protein. The organic matrix composition is proved with Van Gieson trichrome staining (Gerasimova et al., 2015; Zhuravlev, Gerasimova, 2015).

Arranged micropores and canals are specific for the tissue. As a rule, denticle bears a central canal (or chain of pores) and series of pores composing cone-like structures (Fig. 4). The canals and pores in the albid tissue are isolated from basal cavity and have small size. The canal diameter is about $3-4 \mu \mathrm{m}$, pore size ranges from 0.2 up to $4 \mu \mathrm{m}$, total porosity of the tissue according to microtomography is about $1-4 \%$ (Zhuravlev, Gerasimova, 2015).
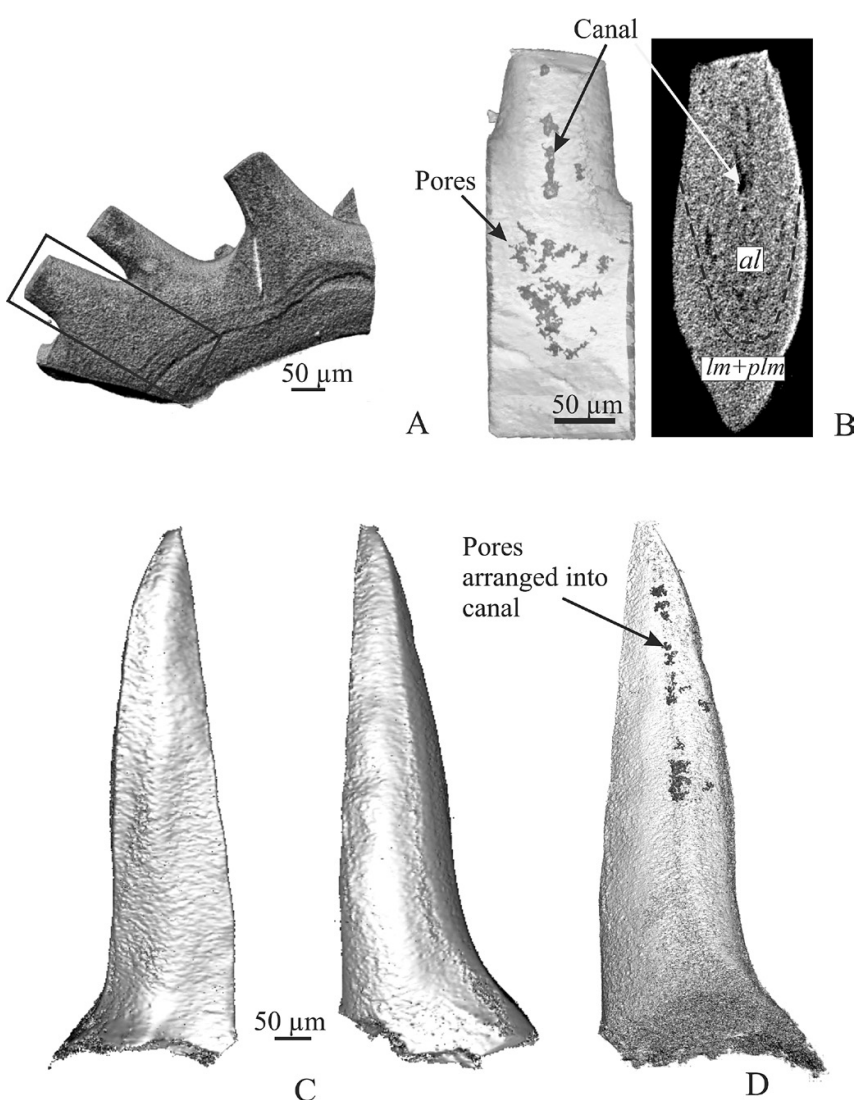

Fig. 4. Pores and canals in the albid tissue. A, B - the S element of the FrasnianPolygnathida (A - general view, B $3 \mathrm{D}$ model and tomographical section of the denticle, showing form and distribution of the pores and canals). Legend: al albid tissue, $l m+p l m-$ lamellar and paralamellar tissues. C, $\mathrm{D}$ - coniform element of the Early Famennian Jablonnodus (C - general view, D - 3D model, showing form and distribution of the pores).

Рис. 4. Поры и каналы в альбидной ткани: A, B - S-элемент франской полигнатиды (A - общий вид; B - 3D-модель и томографический срез зубца, демонстрирующий форму и распределение пор и каналов). Условные обозначения: al альбидная ткань, $l m+p l m$ - ламеллярная и параламелярная ткани. C, D - конический элемент раннефаменского Jablonnodus (C - общий вид, D - 3D-модель, показывающая форму и распределение пор)

Albid tissue has gradual boundaries with other tissues. SEM image demonstrates a gradual transition from the lamellar to albid tissue (Fig. 5). The transition zone is characterized by rare pores and clearer lamellar structure. So the albid/lamellar tissues junction is not sharp, in contrary to data of Ph. Donoghue (1998). 


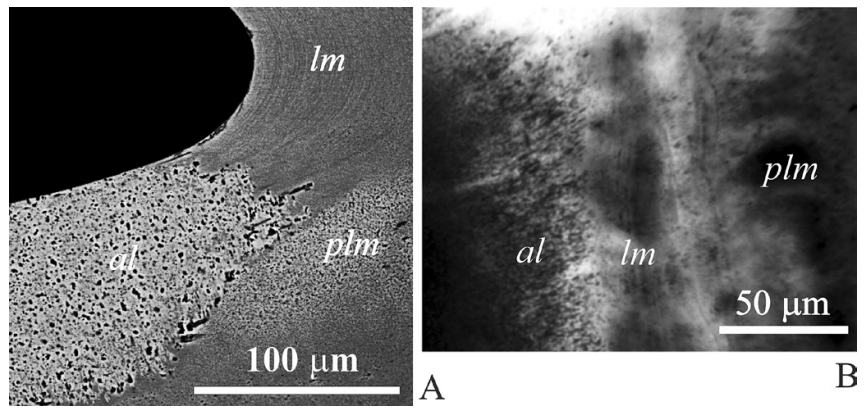

Fig. 5. Gradual transition from the lamellar to the albid tissue. A - SEM image of the albid / lamellar tissue junction; Sbelement of the Middle Frasnian (Late Devonian) Youngquistognathus. B - Light microscopic image of thin-section of the Pa element of the Middle Frasnian (Late Devonian) Youngquistognathus. Legend: al - albid tissue; Im- lamellar tissue; plm paralamellar tissue

Рис. 5. Постепенный переход от ламеллярной к альбидной ткани. А - СЭМ-изображение сочленения альбидной и ламеллярной тканей; Sb-элемент среднефранского (поздний девон) Youngquistognathus; В - изображение в световом микроскопе шлифа Ра-элемента среднефранского (поздний девон) Youngquistognathus. Условные обозначения: al - альбидная ткань; lm - ламеллярная ткань; plm - параламеллярная ткань

The albid tissue, appearing in the Late Cambrian Early Ordovician (Barnes, Sass, Monroe, 1973; Lindstrom, 1964), changed during the conodont history. Our investigation demonstrates increasing of structure ordering and complexity of the albid tissue during the Palaeozoic (Gerasimova et al., 2015). The changes are considered as evolutionary ones.

The Late Palaeozoic conodonts demonstrate a clear trend to reducing the structures composed by albid tissue. This tendency is observed in some lineages at the generic level: Alternognathus -Siphonodella; Scaphygnathus Clydagnathus - Cavusgnathus; Protognathodus Gnathodus - Declinognathodus - Neognathodus; and Protognathodus - Gnathodus - Idiognathodus. So, some conodonts have no structures composed of this tissue, and presence of the albidtissue is not an obligatory feature of conodont elements, including the Late Palaeozoic ones.

\section{Paralamellar tissue}

The paralamellar tissue demonstrates a lamellar structure consisting of elongated crystallites (about $0.5 \mu \mathrm{m}$ thick, and $2-3 \mu \mathrm{m}$ long). This tissue differs from the lamellar one by a lower content of the organic matter, and by a presence of small scattered pores $0.3-1.8 \mu \mathrm{m}$ in diameter. Total porosity of the paralamellar tissue is up to $6 \%$ according to microtomography. Unlike to the albid tissue, the paralamellar tissue is characterized by a lower ordering of the larger crystallites (Zhuravlev, 2002), which are not composing a mesocrystal texture (Fig. 6). The $\mathrm{Ca} / \mathrm{P}$ ratio (wt. \%) in the paralamellar tissue of the unaltered conodont elements $(\mathrm{CAI}=1)$ is 2.11 according to the microprobe data. Thermally altered conodont elements $(\mathrm{CAI}=5) \mathrm{dem}-$ onstrate higher $\mathrm{Ca} / \mathrm{P}$ ratio (about 2.31).

This tissue type appears to be intermediate between lamellar and albid tissues. As a rule, the paralamellar tissue composes lateral parts of the conodont element processes and platforms. In some clades the paralamellar tissue re- places the albid tissue in the denticles of the carina. The structures of paralamellar tissue are regenerated by lamellar or paralamellar tissue (Zhuravlev, 2004).

It is interesting to note that the hard tissues of conodonts can replace each other during the regeneration of the damaged parts (Zhuravlev, 2004). The regeneration comprises three stages: forming of node composed of lamellar tissue, which covers the fracture surface; restoring the initial form of the element by the structure composed of lamellar tissue; forming the core of albid tissue (if it presents in the uninjured part of the element) (Fig. 7) (Zhuravlev, 2004).

The style of conodont element regeneration differs from the regeneration of hard tissues of Vertebrata. For example, enamel and enameloid are not regenerated at all (Klatsky \& Fisher, 1953), and regeneration of dentine and bone tissues is realized with the same tissue only.

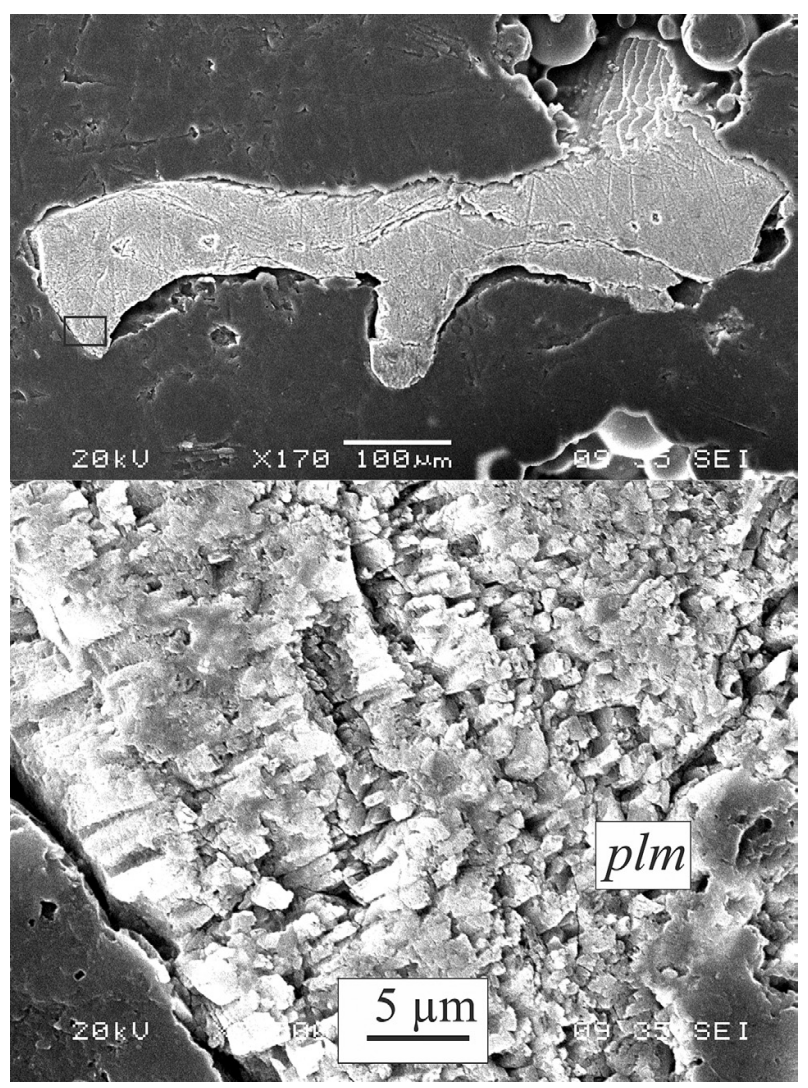

Fig. 6. Slightly disordered crystallites of the paralamellar tissue. SEM image of the Pa element cross section of the Late Tournaisian (Early Carboniferous) Siphonodella quadruplicata (Branson et Mehl)

Рис. 6. Слегка разориентированные кристаллиты параламеллярной ткани. СЭМ-изображение поперечного сечения Ра-элемента позднетурнейской (ранний карбон) Siphonodella quadruplicata (Branson et Mehl)

Differences and similarities of conodont and vertebrate hard tissues

Lamellar tissue differs from the enamel and enameloid by higher content (up to 3 vol. \%) and different composition of organic matter (collagen vs amelogenins), smaller cristallites of the F-apatite (fluorapatite), having different lattice parameters (see also Nemliher, Kallaste, 2012), and presence of regeneration of the fractured parts. 
Supposed similarity of the lamellar and interlamellar tissues and lamellar bone (Sansomet al., 1992) is not proved by crystallite arrangement and organic matter distribution. The lamellar tissue demonstrates a higher ordering of the crystallites and lack of the plywood-like structure that is characteristic for the lamellar bone (Weiner, Traub, Wagner, 1999).

Albid tissue differs from all the known phosphate hard tissues in an extremely high crystallinity (forms porous mesocrystal) in association with small amount of a collagen-like organic matter. The cellular bone, dentine, and mesodentine demonstrate much lower crystallinity and higher content of organic matter. The pores and canals of the albid tissue, possessing size similar to the lacunae and canaliculi of a cellular bone, show other configuration and spatial distribution. The albid tissue regeneration is unlike to regeneration of bone and dentine as well. The only common features of albid tissue and dentine are an organic matrix represented by collagen-like proteins, and mineral part composed of calcium phosphate. So, it seems that albid tissue is homological neither to dentine, nor to vertebrate bones.

\section{Conclusions}

In spite of obvious differences between texture and composition of the conodont hard tissues and those of Vertebrata some analogues in biomineralization mechanisms occur. For example, supposed stages of the albid tissue formation (Gerasimova et al., 2015; Zhuravlev, Gerasimova, 2015) are close to those of any hard tissues secreting by biologically controlled extracellular mineralization (Weiner and Dove, 2003). This similarity may be caused by a similar process of biominiralization, not by synplesiomorphy.

\section{Acknowledgments}

S. Shevchuk and $V$. Filipov are thanked for the microprobe study. Anonymous reviewers are thanked for valuable comments improving the manuscript. The investigations were supported by the Uralian Branch of RAS Grant \#1518-5-37.

\section{References}

1. Barnes C. R., Sass D. B., Poplawski M. L. S. Conodont ultrastructure: the Family Panderodontidae. ROM Life Sciences Contribution. 1973, 90, 36 p.

2. Barnes C. R., Slack D. J. Conodont ultrastructure: the Subfamily Acanthodontinae. ROM Life Sciences Contribution.1975,106, $21 \mathrm{pp.}$

3. Barnes C. R, Sass D. B., Monroe E. A. Ultrastructure of some Ordovician conodonts. The Geological Society of America Special Paper 141, 1973, pp. 1-30.

4. Blieck A., Turner S., Burrow C. J., Schultze H.-P., Rexroad C. B., Bultynck P.,\&Nowlan G. S. Fossils, histology, and phylogeny: why conodonts are not vertebrates. Episodes, 2010, 33, pp. 234-241.

5. Briggs D. E. G. Conodonts - a major extinct group added to the vertebrates. Science. 1992, 256, pp. 1285-1286.

6. Donoghue P. C. J. Growth and patterning in the conodont skeleton. Phil. Trans. Royal Society London, B, 1998, 353, pp. $633-666$.
7. Donoghue P. C. J., Chauffe K. M. Conchodontus, Mitrellataxis and Fungulodus: conodonts, fish or both? Lethaia, 1998, 31, pp. 283-292.

8. Donoghue P. C. J., Forey P. L. \& Aldridge R. J. Conodont affinity and chordate phylogeny. Biological Reviews, 2000, 75, pp. 191-251.

9. Frank-Kamenetskaya O. V., Rozhdestvenskaya I. V., Rosseeva E. V., \& Zhuravlev A. V. Refinement of Apatite Atomic Structure of Albid Tissue of Late Devon Conodont Crystallogr. Rep., 2014, 59(1): 41-47.

10. Gerasimova A. I., Zhuravlev A. V., \& Rosseeva E. V. Structure and origin of the albid tissue of conodonts 3rd ISPH PROGRAM and ABSTRACT BOOK, Bonn, July 2-5, 2015, pp. 81 .

11. Janvier P. Conodonts join the club. Nature 374. 1995, pp. 761-762.

12. Kasatkina A. P., Buryi G. I. The position of the phyla Chaetognatha and Euconodontophylea in the classification of Metazoa. Zoosystematica Rossica, 1999, 8(1), pp. 21-26.

13. Kemp A. Hyaline Tissue of Thermally Unaltered Conodont Elements and the Enamel of Vertebrates. Alcheringa, 2002, 26(1), pp. 23-36.

14. Klatsky M., Fisher R. L. The human masticatory apparatus: an introduction to dental anthropology. Brooklyn: Dental Items of Interest, 1953, $246 \mathrm{p}$.

15. Lindstrцm M. \& Ziegler W. Feinstrukturelle Untersuchungenan Conodonten.1. Die Uberfamilie Panderodontacea. Geologica et Palaeontologica. 1971, 5, pp. 9-33.

16. Murdock D. J. E.; Dong X.-P.; Repetski J. E.; Marone F.; Stampanoni M. \& Donoghue P. C. J. The origin of conodonts and of vertebrate mineralized skeletons. Nature, 2013, 502, pp. 546-549.

17. Müller K. J. \&Nogami Y. Entoken und Bohrspurenbei den Conodontophorida. Palaont, Z. 1972, 46(1), pp. 68-86.

18. Mbller K. J.\&Nogami Y. Uber den Feinbau der Conodonten. Memoirs of the Faculty of Science, Kyoto University, Series of Geology and Mineralogy. 1971, 38(1), pp. $1-87$.

19. Nemliher J., Kallaste T. Conodont bioapatite resembles vertebrate enamel by XRD properties. Estonian Journal of Earth Sciences. 2012, 61(3), pp. 191-192.

20. Pander C. H. Monographie der fossilen Fische des silurischen Systems der russischbaltischen Gouvernments. St. Petersburg, 1856, $91 \mathrm{pp}$.

21. Pierce R. M. \&Langenheim R. L. Ultrastructure in Palmatolepis sp. and Polygnathus sp. Geological Society of America, Bulletin, 1969, 80(7), pp. 1397-1400.

22. Purnell M. A., Aldridge R. J., Donoghue P. C. J. $\&$ Gabbott S. E. Conodonts and the first vertebrates. Endeavour. 1995, 19(1), pp. 20-27.

23. Rosseeva E., Borrmann H., Cardoso-Gil R., CarrilloCabrera W., Frank-Kamenetskaya O. V., Цztan Y., Prots Y., Schwarz U., Simon P., Zhuravlev A. V., and Kniep R. Evolution and Complexity of Dental (Apatite-Based) Biominerals: Mimicking the Very Beginning in the Laboratory. Max-PlanckInstitut for Chemische Physik fester Stoffe, Scientific Report 2009-2010, 2011, pp. 171-176.

24. Sansom I. J., Smith M. P., Armstrong H. A. \& Smith M. M. Presence of the earliest vertebrate hard tissues in conodonts. Science, 1992, 256, pp. 1308-1311.

25. Sansom I. J., Smith M. P. \& Smith M. M. Dentine in conodonts. Nature, 1994, 368, pp. 591.

26. Trotter J. A., Fitz Gerald J. D., Kokkonen H. \& Barnes C. R. New insights into the ultrastructure, permeability, and in- 
tegrity of conodont apatite determined by transmission electron microscopy. Lethaia, 2007, 40, pp. 97-110.

27. Turner S., Burrow C. J., Schultze H.-P., Blieck A., Reif W.-E., Rexroad C. B., Bultynck P. \&Nowlan G. S. False teeth: conodont-vertebrate phylogenetic relationships revisited. Geodiversitas, 2010, 32, pp. 545-594.

28. Weiner S. \& Dove P. M. An overview of biomineralization processes and the problem of the vital effect. Reviews in Mineralogy and Geochemistry, 2003, 54, pp. 1-29.

29. Weiner S., Traub W., Wagner H.D. Lamellar bone: structure-function relations. J. Struct. Biol. 1999, 126(3), pp. 241-55.

30. Wright J. Conodont geochemistry: a key to the Palaeozoic. Courier Forschungsinstitut Senckenberg, 1990, 118, pp. 227-305.

31. Zhuravlev A.V. A new type of conodont hard tissue. Lethaia, 2002, 35(3), pp. 275-276.
32. Zhuravlev A. V. \& Sapega V. F. XRD data on composition of the hard tissues of the Late Palaeozoic conodonts. In: Bio-Inert Interactions: Life and Rocks. Materials of the 3rd International Symposium, VSEGEI, St. Petersburg. 2007, pp. 63-64 [in Russian, English abstract]

33. Zhuravlev A. V. Morphological and histological aspects of conodont element regeneration . Paleontol. J., 2004, 38(3), pp. 307-310.

34.Zhuravlev A. V., Gerasimova A. I. Albid tissue of the conodont elements: composition and forming model. Vestnik IG Komi SC UB RAS, 2015, 10, pp. 21-27. [in Russian, English abstract].

35. Zhuravlev A. V., Sokiran E. V., Evdokimova I. O., Dorofeeva L. A., Rusetskaya G. A., \& Małkowski K. Faunal and facies changes at the Early-Middle Frasnian boundary in the north-western East European Platform //Acta Palaeontologica Polonica. 2006. 51(4). P. 747-758. 